\title{
Introduction. Environmental Politics in Urban India
}

\section{Anna Zimmer and Natasha Cornea}

\section{OpenEdition}

\section{Journals}

Electronic version

URL: http://journals.openedition.org/samaj/4247

DOI: 10.4000/samaj.4247

ISSN: $1960-6060$

Publisher

Association pour la recherche sur l'Asie du Sud (ARAS)

Electronic reference

Anna Zimmer and Natasha Cornea, «Introduction. Environmental Politics in Urban India », South Asia Multidisciplinary Academic Journal [Online], 14 | 2016, Online since 24 October 2016, connection on 30 April 2019. URL : http://journals.openedition.org/samaj/4247 ; DOI : 10.4000/samaj.4247

This text was automatically generated on 30 April 2019

\section{$(1) \Theta \Theta$}

This work is licensed under a Creative Commons Attribution-NonCommercial-NoDerivatives 4.0 International License. 


\title{
Introduction. Environmental Politics in Urban India
}

\author{
Anna Zimmer and Natasha Cornea
}

1 This special issue seeks to throw light on environmental politics in contemporary urban India. Herein we adopt a deliberately broad definition of the urban environment to include urban natural resources, environmental amenities and services, and the built environment ${ }^{1}$ (Véron 2010). Drawing on Grove (2009:209) we understand urban environmental politics as designating the "struggles over

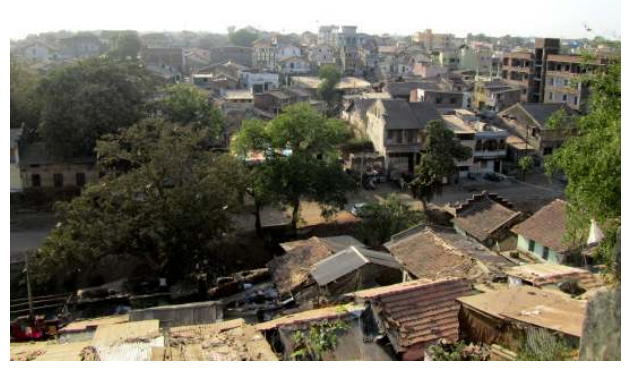
meanings and practices of nature and the city that shape identities that make some forms of urban metabolisms possible while foreclosing others." ${ }^{2}$ The collection of papers that form this issue explore environmental politics in a broad range of cities, from the more often discussed metros including Delhi, Bangalore, and Chennai, but also the politics of the smaller centres of Puri and Leh. Utilising diverse entry points and theoretical orientations these cases each contribute to an interlinked set of discussions about the politicisation of India's urban environment. Specifically, they explore the way that the environment is entwined with questions of urban citizenship; the role environmental knowledge(s) plays in urban environmental politics; and the situated character of urban political ecologies.

In the Indian context, the endeavour to trace urban environmental politics must take into account the current and recent upheavals in India's cities. It is widely acknowledged that the liberalisation policies of the 1990s have brought about fundamental shifts not only in the Indian economy, but also in the society; especially in India's cities. Shatkin (2014:8) argues that the urban political terrain is undergoing fundamental transformation as well. Bhan (2010) therefore states that the urban has "begun to rise not just demographically but politically, electorally, socially, culturally and economically to become the defining 
problem space of the 'new India'." Due to these recent transformations, but also as a result of the political focus on rural areas that has prevailed through much of India's independence decades, there is still a relative lack of knowledge about current urban local politics (Tawa Lama-Rewal and Zérah 2011). This special issue aims at addressing this gap using the environment as an entry point.

Herein, and throughout this special issue, urbanisation is understood to mean "a political, social, and economic process intertwined with ecological processes and produced through power relations occurring at various scales" (Véron 2006:2094; drawing on Swyngedouw 1997). As cities are socio-environmental entities, the environment and the urban are fused together in a hybrid process. With this conceptualisation, it is obvious that the larger socio-economic and political shifts previously mentioned have environmental dimensions. On the one hand, they have environmental effects brought about by economic growth and increased consumption, as well as sustained urbanisation (Shaw 2007). As Rademacher and Sivaramakrishnan (2013:1) note, "rapidly proliferating and resource-intensive urbanism affect[s] everyday lived environments and the ecological processes that undergird them." This becomes apparent in phenomena like air pollution (Sharan 2013, Véron 2006), water pollution and depletion (Sharan 2014), increased vehicular traffic (Pucher et al. 2005), increasing difficulties to find space for solid waste management (Bose and Blore 1993, Hazra and Goel 2009, Gidwani and Reddy 2011, Idris, Inanc, and Hassan 2004,), loss of forest cover (Sharma and Joshi 2015), and growing tendencies toward the Urban Heat Island effect (Roy and Singh 2015) among others. These environmental issues are understood as highly political and closely intertwined with the production of uneven cityscapes, wherein it is the poor who often bear the greatest burden of environmental degradation (Véron 2006).

On the other hand, societal shifts have often been squarely and fundamentally inscribed in urban environments in the sense that this change has come about precisely through the change in environmental practices. The changing consumption patterns just mentioned are part of these. In addition, other practices have been introduced in the course of economic liberalisation, during which the "environment" and "environmental problems" in urban areas have increasingly become the focus of governance efforts by both state and non-state actors in urban India (Mawdsley 2003). Due to this enhanced visibility of the environment and environmental problems in India's cities, Follmann (2015) argues that India is currently witnessing an "urban environmental awakening." This renewed impetus to address environmental issues is to a very large extent a result of the recognition of powerful actors that "[i]n order [for India] to realise its medium-term growth potential, an essential prerequisite is to manage and facilitate the process of urbanisation" (Ahluwalia, Kanbur and Mohanty 2014:2), including urban environmental problems. The government is called upon by global players, such as UN-Habitat, to address issues of environmental sustainability in order to maintain cities' competitiveness (UN-Habitat 2010:162), as environmental degradation threatens to affect investment flows (Upadhyaya 2014) and endanger sustainable economic growth (The World Bank 2001). The meaning and value of urban environments have thus changed along with the larger politico-economic shifts that have placed Indian cities at the forefront of global competition (Coelho and Raman 2013:146). It can therefore be stated that the environment of metropolitan cities at least has been an integral component of the restructuration and urban "renewal" of cities on their way to becoming "world-class" (Arabindoo 2010, Fernandes 2004, Follmann 2015, Ghertner 2011, Truelove and 
Mawdsley 2011). Interventions aiming at environmental upgrading are therefore also highly politicised processes, inscribed into the specific political economy of contemporary post-liberalisation Indian cities (Shatkin 2014).

5 These interventions have often taken the form of an aesthetic "upgrading" (see also Müller and Dame, this issue). City beautification and urban ecological restoration have emerged as "idioms through which the cities position themselves in the global arena as well as direct strategies for capital accumulation through real-estate value" (Coelho and Raman 2013:147), and the notion of "clean and green" cities has become a buzzword in the new image-building processes of India's cities (Follmann 2015). These processes, as we shall see, often have a markedly classed character: Fernandes (2004:2416) documents how "new urban aesthetics and assertive claims on public urban space" by India's new middle classes lead to beautification projects that include the displacement of the poor (Zimmer, Cornea and Véron 2016). This, however, is not to say that urban environmental improvement is not demanded by the urban poor as well (Chaturvedi 2010)

The remainder of this introduction is devoted to discussing three aspects of the politicisation of India's urban environment in more detail: the way the environment is entwined with questions of urban citizenship; the role environmental knowledge plays in urban environmental politics; and the situated character of urban political ecologies. We briefly outline the contributions of this special issue to each of these debates. A conclusion follows.

\section{Urban citizenship and city-making}

7 Holston (2009:12) defines urban citizenship as: "A citizenship that refers to the city as its public sphere and to rights-claims addressing urban practices as its substance-claims concerned with residence, neighbourhood life, infrastructure, transportation, consumption and so forth." As Desai and Sanyal (2012:2) following the work of Holston and Appadurai (1999), point out, Indian cities have become-and have become recognised as-crucial spaces in which the meanings of citizenship are negotiated and contested. Because negotiating citizenship in the city "means asking difficult questions of inclusion, exclusion, equality and belonging" (Bhan 2010) some of these negotiations are centred on the way class is bound up with the substantive aspects of citizenship. For example Fernandes (2004) argues that definitions of citizenship in urban India have come to be based almost exclusively on the new middle classes and defined by their practices of consumption.

8 The Indian government, through urban programmes such as the Jawaharlal Nehru National Urban Renewal Mission (JNNURM), pushes a concept of the citizen-turnedstakeholder. Roy (2014) argues that this links citizenship with the capability to pay for public services, which leads to a new category of "consumer-citizen" (Harriss 2007:2722). Ghertner (2013:266), as well, finds articulations of understandings of citizenship with the ownership of property. The same author (2011) sees a deepening of exclusionary citizenship (at least in Delhi), as traditional ways of accessing the state are closing down for the poor. As a result, Truelove and Mawdsley (2011:408) state that discourses around citizenship "are increasingly being entrenched around class identities." Thus the middle classes are, following Chatterjee (2004), frequently defined as the "proper citizens" of India's urban agglomerations. However, this categorisation which draws on Gramsci (Chandra and Majumdar 2013) is rejected by Holston (2012) as dichotomous and 
homogenising. A more complex understanding of exclusionary citizenship is offered by Desai (2012) who analyses how class, religious and regional identity are enmeshed in producing an exclusionary citizenship in Gujarat, and particularly in Ahmedabad. The papers in this issue are broadly sympathetic to approaches such as Desai's (2012) that situate analysis within local complexity and acknowledge the intersectionality of factors beyond class. Doing so allows for a more nuanced understanding of processes of exclusion.

While an emerging set of case studies have begun to explore how exclusionary citizenship is as much an environmental concept as it is an urban one, and connections have been made between on the one hand experiences and performance of citizenship, and on the other hand urban environmental practices and politics. We suggest that further exploration of these complex processes is needed.

10 A number of recent works demonstrate the important role the environment plays in negotiations of citizenship in India's large metropolises. The case of Delhi seems to have attracted special interest, perhaps because the contestations here have proven to be especially violent (Baviskar 2003). Gidwani and Chaturvedi (2011:77), working on informal solid waste management in the city, state that new SWM practices reinforce the distinction between "valuable lives, [and] wasted lives," leading to informal waste-pickers and recyclers being excluded from political citizenship and finding their "political claims to the city ... suppressed in favour of upper-class demands" (Gidwani and Chaturvedi 2011:67). Other cases show how environmental protection is enmeshed with often violent renegotiations and the further demarcation of boundaries around an exclusively defined citizenship. Air pollution abatement in Delhi has been the expression of a bourgeois environmentalism which included "demonizing an increasingly illegalized working class ... as environmental offenders" (Kumar 2012:150), while at the same time recognising a restricted number of interest groups as citizens through the Bhagidari scheme (Kumar 2012:140). Claims especially by auto-rickshaw drivers, and environmental priorities by non-elite groups of residents have been side-lined in the process (Sharan 2013, Véron 2006). Indeed the extension of such processes can be seen in the current controversy surrounding diesel taxis in Delhi. Under the banner of environmental improvement, poor citizens of Delhi have found their right to occupy space in the city severely curtailed (Baviskar 2003, Ghertner 2011). Such displacements from physical and political space have been enabled through an alliance between middle and upper class interests that has served to define a "proper environmental citizen" (Truelove and Mawdsley 2011:408). Similarly, in Bangalore Ranganathan (2011) explains how water (and the access to it in piped form) became enmeshed in citizenship claims of lower middle class and middle class residents of unauthorised colonies at the urban fringe. Paying beneficiaries' contributions to a new water supply scheme here served to "demonstrate that they form a legitimate part of the responsible citizenry" (174).

Within this special issue a number of papers engage with citizens' claims on or for the city and with questions of the performance of citizenship. This occurs in diverse arenas and is shaped by interactions with a range of actors. Rao Dhananka and Hagn examine the articulation between citizenship and housing/property ownership in India. Rao Dhananka's paper employs two case studies from Bangalore to argue that patterns of land allocation and the resulting forms of habitation of the urban poor have shaped politicised definitions of urban citizenship. Hagn's contribution explores the way the access to (or exclusion from) Rajiv Avaaz Yojana, a central government slum- 
redevelopment scheme that is billed as integrated and inclusive, hinges on pre-existing relationships of power that integrate certain cultural and caste groups into the concept of citizenship more fully than others.

Citizenship as practice, involving negotiations between the state and a multiplicity of other actors is highlighted within a number of papers. Both Hagn and Rao Dhananka's contributions highlight the complex nature of participation within political processes. While Woiwode and Hackenbroch's paper on Chennai points to the way that the technospecific approach of Smart Cities neglects people as actors, serving to side-line citizens' involvement, and bringing to the fore questions of participation and accountability in contemporary urban development in India.

For Follmann the Yamuna riverscape is both a bio-physical entity and a heuristic through which to understand the role of particular actors in the contestations over Delhi's urban socio-nature. The author highlights how it is a space for formulating citizenship and as a space to be remade (or not) and as a target for preservation with wide-ranging differentiated effects on lives and livelihoods.

14 At a more abstract level, the papers in this issue contribute several points to the debate outlined above. First, Truelove makes an important point in suggesting that categories of citizenship, and related subjectivities, are in constant flux, and thus temporally not stable. This focus on change complicates debates on inclusion and exclusion substantially -and is further strengthened by the critique of dualism between "citizens" and "noncitizens"-that are present in the papers of Follmann and Truelove. It appears in both that neither urban slums and their inhabitants, nor the middle class can be understood as neatly (and constantly) fitting into the categories of proper or improper citizens. Second, Hagn and Rao Dhananka confirm the link between property and definitions of citizenship, while Truelove stresses the way infrastructure embodies social relationships like the ones around citizenship. Yet, Hackenbroch and Woiwode equally point out that these relationships are embodied in practices of urbanism at different scales. Thus, while the literature recognises the important momentum that pushes practices of consumption to the fore-front of citizenship debates, this issue shows that other practices such as urban planning, and environmental practices remain vital for understanding how citizenship is negotiated in Indian cities. Also, the "citizen-turned-stakeholder" that appears as vital for the functioning of JNNURM is complemented by the insights from Hagn's paper that presents a citizen who manages to navigate the very personal and political networks of power that unfold through RAY in Puri. This, together with Hackenbroch and Woiwode who discuss the unfolding of the Smart City initiative in Chennai, stresses the important ways national flagship programmes aimed at development and environmental improvement of cities and state-level urban environmental policy are entwined with negotiations of citizenship and belonging at the local level.

\section{Environmental knowledge and environmental politics}

15 Knowledge, according to Bayly (1996 in Kalpagam 2014), is socially organised and taxonomised information. Environmental knowledge, then, would designate socially organised information pertaining to the environment. Of course, such knowledge is then in no way a collection of "neutral facts" devoid of politics. Rather, our understanding of environmental knowledge builds on Michel Foucault's (1991:27) insight that "there is no power relation without the correlative constitution of a field of knowledge, nor any 
knowledge that does not presuppose and constitute at the same time power relations." According to Foucault (1997:53) the knowledge-power nexus builds a system of acceptability; a regime of truth that confers to specific information the tag of being "true"-while other information is considered erroneous (Foucault 1997:13-15). These systems of acceptability change over time, so that what is considered truth-or knowledge-is something which is historically situated (Rabinow and Rose 2003). As these systems are never absolute and unchallenged, diverging knowledge claims exist simultaneously. Rademacher (2011:28) points out that many forms of knowledge exist "through which people actually know and engage the environment in social life."

Because of this strong interweaving of knowledge and power, governments and other actors in India and elsewhere have used knowledge strategically to enforce their claims on the environment. Retracing the colonial period, Agrawal (2005) spells out how bureaucratic knowledge about the forest of Kumaon was the basis for governmental attempts to control it. Kalpagam (2014) equally working on colonial India, shows how "[m]odern state forms ... have been instrumental in an epistemological conquest." That environmental knowledge and claims over the environment are still bound together in intimate ways in the postcolony is demonstrated by Baviskar (2000) who analyses the strategic use of scientific and indigenous knowledge by the Forest Department, local villagers, and an NGO respectively in competing claims over use of forest resources within a national park in Himachal Pradesh. Often, technocratic knowledge is in a privileged position when it comes to asserting such claims (Rademacher and Sivaramakrishnan 2013). In the context of interpreting Delhi's wastewater, Karpouzoglou and Zimmer (2016) document how embodied, non-technical knowledge that residents of an unauthorised colony gain in their locality is delegitimised at various levels by state actors. These competing knowledge claims demonstrate that tensions exist between professional expertise and democratic governance, a situation which encourages equal participation in framing and governing environmental issues-in theory at least (Fischer 2000).

Such a politicised view of environmental knowledge entails that science or other forms of knowledge and politics are coproduced. In fact, the evolution of environmental facts and knowledge is integral to wider politics (Forsyth 2004). In India, a case study on Delhi by Véron (2006) demonstrates that the framing of air pollution and possible solutions to it, for example, are highly class-biased. Such case studies heed Forsyth's (2003:131) call "to acknowledge the social embedding of environmental knowledge" and recognise how science can be mobilised for political objectives.

Against this background it becomes clear that there is no clear-cut divide between "state knowledge" and "local knowledge." Rather, as Robbins (2000) demonstrates, competing truths about the environment between knowledge communities that include state as well as non-state actors are based on questions of political economy. The complex positioning of the state is further confirmed by Birkenholtz (2008) who traces the hybridisation of different forms of knowledges about groundwater in Rajasthan. While a redistribution of power-knowledge is attempted through displacement of local knowledge into the state apparatus, the state is currently marginalised there in knowledge production and distribution regarding groundwater. Birkenholtz's (2008:466) statement that "[c]entral to the politics of nature is the question of environmental knowledge, of how it is produced, contested, legitimated, and hybridized" easily maps onto the politics of urban nature, or 
urban environmental politics. And yet, just how these processes play out in the urban context has been studied to a lesser extent.

The contributions to this special issue seek to provide situated understandings of the multiple ways in which environmental knowledges are employed within the political strategies that reproduce India's urban environments. In doing so, the authors all point to the complexity of knowledge communities.

20 A number of authors give particular pride of place to the political nature of "state" knowledge, particularly vis-à-vis Government of India sponsored schemes, such as JNNURM, RAY, and the new Smart Cities initiative that shape environmental knowledges and practices in diverse ways (Hagn, Müller and Dame, Rao Dhananka, Woiwode and Hackenbroch). In Puri, Hagn highlights how lists and maps produced by the state represent a specific, highly politicised type of environmental knowledge, one with a significant effect on the power (im)balances within and between communities. While Müller and Dame highlight how the particular knowledges and particular knowledge makers are mobile and privileged, as with the involvement of Sikkimese town planner and Gangtok as an example for Leh. Woiwode and Hackenbroch, point to the privileging of technological solutions within state environmental knowledges.

21 Yet, Follmann aptly highlights in his contribution that all actors selectively use, deploy and reformulate environmental knowledges to further their specific agendas. By paying attention to everyday knowledge productions Follmann complicates the classed dichotomy presented in other literatures on environmental activism by middle-class NGOs versus the environmental activism of the poor, wherein middle-class efforts are presented as resulting in bourgeois environmentalism (see for example Baviskar 2003).

22 All the papers in this issue therefore highlight that the processes through which knowledge is recognised as such are in dire need of better understanding. Truelove shows that literacy is crucially linked to the question of who is perceived as knowledgeable. ${ }^{3}$ Hackenbroch and Woiwode stress the importance of knowledge that emerges from practice and everyday life which does not get the same weight in policy debates as more technocratic, analytical and abstract knowledge. In short, the production of knowledgeand the way these processes of production are legitimised or not-require our analysis to firmly embed larger processes of city-making into the flows of power/knowledge in the city. That these flows are connected in multiple ways to national and global networks is something that emerges in urban centres of very different sizes (Hackenbroch and Woiwode, Müller and Dame, see also Zimmer, Cornea and Véron 2016) and is not restricted to the large metropolises.

\section{Situated Urban Political Ecology}

23 Turning to the field of Urban Political Ecology (UPE), the issue aims at contributing to the emerging literature on Situated Urban Political Ecologies. UPE as a field ${ }^{4}$ seeks to examine the ways that nature is enrolled in and coproduced through the social, political and economic processes of urbanisation (Swyngedouw and Heynen 2003). Zimmer (2015) has elaborated elsewhere how despite its "critical" and "radical" roots (Watts and Peet 2004), political ecology's engagement with postcolonialism is rather limited (Kim et al. 2012, Müller and Dame, this issue). A collection on "Other Political Ecologies" (Kim et al. 2012) raises the important question of authorship and gathers works by scholars who do not 
identify with the label "Western" in both rural and urban contexts of various countries. Nevertheless, Lawhon, Ernstson, and Silver (2014) claim that UPE as a sub-field has so far suffered from an unnecessarily limited empirical base that has led the field to conceptual constraints as well. Building on African case studies, they argue that a focus on the everyday, as well as a more diffuse understanding of power emerge from struggles over more just and sustainable urban environments here. Moreover, they hold that such an approach can help in building the argument for incremental political changes (see also: Lawhon et al. 2016). A focus on the everyday is also favoured by Shillington (2012:296) who holds that the "politics embedded in everyday life" are worth UPE's examination (see also Loftus 2012, Silver 2015, Cornea, Zimmer and Véron 2016). We are broadly sympathetic to such a focus and this is reflected in the papers in this issue.

Based on South Asian case studies, Zimmer (2015) puts forward the importance of enriching UPE's theoretical base with concepts that arise from this context, such as that of the everyday state, and acknowledgement of a greater complexity of urban society in order to better understand the production of urban environments. Having the thoroughly and historically fragmented societies of postcolonial cities in mind, Ernstson (2014:3) holds that UPE here requires "practices that stage ... disagreements, that make ... antagonistic readings of the city and its nature clear and debatable so as to push these deep disagreements into the political process of how the city is governed." At the same time, a situated UPE should avoid over-generalisation of any "Southern" UPE (and see Lawhon 2013, for this point regarding environmentalism) that clubs together vastly heterogeneous continents, histories, and identities.

Few Indian case studies exist that explicitly use a UPE framework so far. Ghertner ${ }^{5}$ (2011) shows how the world-class discourse in Delhi creates a new aesthetic that makes it possible to map environmental pollution onto the bodies and settlements of the urban poor, and ask for removal of the "nuisance" both represent. Truelove's (2011) case study of Delhi spells out how everyday water practices in Delhi reproduce multiple social differences (see also Truelove's contribution to this issue). The concept of the everyday state, in turn, is identified by Ranganathan and Balasz (2015) as a concept of major importance that emerges from their analysis of two case studies situated in Bangalore, India, and the USA. Moreover, highlighting the diverse framing of access to water in both geographical contexts, and in the Environmental Justice and UPE debates respectively, these authors spell out how the Indian case draws attention to the political process of accessing water, and the framing of water as a matter of citizenship claims. Zimmer, Cornea and Véron (2016) explore the politics of a globally-connected local elite involved in the removal of marginalised urban residents from the centre of a Gujarati town to the periphery where a slum is resettled next to the municipal garbage dump. Global financial flows through the Rotary Foundation and party politics play crucial roles in this production of uneven socio-nature. Cornea, Zimmer and Véron (2016) also highlight the role of party politics in shaping access to urban ponds in a small town in West Bengal. There, everyday access is achieved by marginalised groups through diverse strategies that include: affiliation to political parties and/or neighbourhood clubs, often translated into unspecified threats; moral norms of support for the poor; and the (in)visibility of specific ponds within bureaucratic processes. While Demaria and Schindler (2016) draw on industrial ecology and environmental economics to situate their analysis of opposition to waste-to-energy schemes in the National Capital Region. They demonstrate how the waste-to-energy initiative sought to develop a particular metabolic configuration 
consolidating waste in a single value chain-producing a situated political ecology where the spaces in which waste is collected/processed become a "commodity frontier" (Demaria and Schindler 2016:306). They suggest that the emergence of such frontiers inside of cities such as Delhi may lead to urban conflicts that "increasingly resemble resource conflicts" (Demaria and Schindler 2016:309) more commonly seen in rural areas.

Such framings and strategies spelled out in empirical cases allow us to argue that while it is true that urban ecologies are produced in a context of "embeddedness in multiple elsewheres" (Mbembé and Nuttall 2004) and are profoundly-and often globally -"networked" (Lawhon 2013) the Indian case studies have particular contributions to make in their own way. A number of the papers suggest new focusses of analyses or the need to examine resources in new ways to be reflective of the particular context in which their study is situated. Follmann (this issue) utilises the concept of the "riverscape" to encompass the river not just as water or the riverfront but as a space which is at the intersection of the two. His analysis points to the importance of understanding hybrid spaces that do not fit into the land/water binary (see also Lahiri-Dutt and Samanta 2013, Lahiri-Dutt 2014). A similar concept of the "pondscape" is utilised in Cornea, Zimmer and Véron (forthcoming). Both works show how non-piped water is enrolled within the political processes that re-produce particular urban political ecologies in Indian cities. By connecting to a broader concern with water in UPE, Follmann (this issue) and Truelove (this issue) further contribute to understandings of how the "urban waterscape is tied to socially differentiated forms of power, authority, marginality, and precariousness" (Truelove paragraph 7). These contributions also complicate the over-simplistic understandings of marginalisation and presumed dualisms present in some UPE accounts. As noted previously Follmann contradicts the normalised assumption that the middleclass work against the poor within environmental activism in Delhi. In her study of differentiated water practices in a Delhi slum, Truelove (this issue) de-centres the equally normalised account of how urban water experiences are gendered as she finds that the greatest embodied hardship is for single working men who are rarely able to access the intermittent and unreliable water distribution that serves their community. These papers further contribute to the focus within SUPE studies on the everyday, demonstrating that a fine-grained analysis of everyday practice serves to highlight the role of "situated and distributed forms of power in shaping incongruent urban environments" (Truelove this issue).

Müller and Dame (this issue) highlight the need to engage with the "powerful imagination on which ideas about the creation of urban nature are grounded." They highlight how imaginaries of: tourism, based on relaxation and consumption; historical conservation; and cultural imaginaries have shaped processes of beautification in Leh (Ladakh). At the same time, their paper notes how imaginaries have shifted over time. The town was a crucial international trade centre, but became seen as a dangerous national periphery in the new nation state. Recently, it has been incorporated into national romantic imaginaries of life in mountainous areas.

This temporal dimension is further elaborated on in Truelove's paper from which an important theoretical contribution to SUPE literature emerges. She stresses the way actor assemblages around urban nature and urban environmental experiences are fluid and shifting, and highlights the rhythms of urban environmental practices. Her paper therefore makes a case for a more temporally oriented UPE which puts not only 
geographical differences and particularities centre stage, but also pays heightened attention to the temporal dynamics and situatedness of urban political ecologies.

\section{Conclusion}

Taken together the papers in the special issue provide a number of methodological and analytical contributions to the existing literatures on environmental politics in India and to the hereto limited UPE case-studies of Indian cities. Methodologically they have demonstrated that finally-grained analysis of everyday practices and situated dynamics, made possible through extended qualitative engagement, yields rich analytical findings. They have also highlighted the importance of accounting for temporality within data collection and analysis. Analytically they have further nuanced our understanding of environmental politics in India. Through the exploration of diverse field sites, particularly non-metro cities, but also the careful consideration of liminal spaces within dominant cities, such as riverscapes, and the socio-cultural frontiers within neighbourhoods, these papers have pointed to the heterogeneity of urban environments on the one hand and the interconnected nature of environmental politics on the other. In doing so, they highlight the analytical challenge of accounting for local context and specificity while also recognising the multi-scalar political-economic and social factors that shape the reproduction of particular urban environments. Further, it has brought to the fore a need to recognise and account for intersectionality in ways that complicate class binaries in order to understand contemporary power dynamics in Indian cities. By demonstrating the multiple ways in which urban environments in India are increasingly enrolled into a broader reimaging of the role of cities and citizens, this special issue has pointed to the need to critically engage with multi-dimensional and multi-scalar relations of power that shape the material and socio-cultural infrastructures of daily life in Indian cities.

\section{BIBLIOGRAPHY}

Agrawal, Arun. 2005. "Environmentality: Community, Intimate Government, and the Making of Environmental Subjects in Kumaon, India." Current Anthropology 46(2): 161-90.

Ahulwalia, Isher Judge, Ravi Kanbur and P. K. Mohanty. 2014. "Challenges of Urbanization in India: An Overview." Pp. 1-28 in Urbanisation in India: Challenges, Opportunities, and the Way Forward, edited by I. J. Ahulwalia, R. Kanbur and P. K. Mohanty. New Delhi: Sage.

Angelo, Hillary and David Wachsmuth. 2015. "Urbanizing Urban Political Ecology: A Critique of Methodological Cityism." International Journal of Urban and Regional Research 39(1): 16-27. doi: 10.1111/1468-2427.12105.

Arabindoo, Pushpa. 2010. "Isolated By Elitism: The Pitfalls Of Recent Heritage Conservation Attempts In Chennai." Pp. 155-60 in New Architecture and Urbanism: Development of Indian Traditions 
, edited by D. Prashad and S. Chetia. Newcastle upon Tyne: Cambridge Scholars Publishing in association with GSE Research.

Baviskar, Amita. 2000. "Claims to Knowledge, Claims to Control: Environmental Conflict in the Great Himalayan National Park, India." Pp. 101-19 in Indigenous Environmental Knowledge and its Transformations: Critical Anthropological Perspectives, edited by R. F. Ellen, P. Parkes and A. Bicker. Amsterdam: Harewood Academic.

Baviskar, Amita. 2003. "Between Violence and Desire: Space, Power, and Identity in the Making of Metropolitan Delhi.“ International Social Science Journal 55(175): 89-98.

Bhan, Gautam. 2010. “A Republic of Cities.” The Indian Express, January 26. Retrieved February 10, 2016 (http://archive.indianexpress.com/news/a-republic-of-cities/571695/).

Birkenholtz, Trevor. 2008. “Contesting Expertise: The Politics of Environmental Knowledge in Northern Indian Groundwater Practices.” Geoforum 39(1): 466-82.

Bose, Anu and Ian Blore. 1993. "Public Waste and Private Property: An Enquiry into the Economics of Solid Waste in Calcutta." Public Administration and Development 13(1): 1-15.

Chandra, Uday and Atreyee Majumder. 2013. "Introduction: Selves and Society in Postcolonial India.” SAMAJ 7. Retrieved 25, 2016 (http://samaj.revues.org/3631).

Chatterjee, Partha. 2004. The Politics of the Governed: Reflections on Popular Politics in Most of the World . New York: Columbia University Press.

Chaturvedi, Bharati, ed. 2010. Finding Delhi: Loss and Renewal in the Megacity. New Delhi: Penguin.

Coelho, Karan and NV Raman. 2013. "From the Frying Pan to the Floodplain: Negotiating Land, Water, and Fire in Chennai's Development." Pp. 145-68 in Ecologies of Urbanism in India: Metropolitan Civility and Sustainability, edited by K. Sivaramakrishnan and A. Rademacher. Hong Kong: Hong Kong University Press.

Cornea, Natasha, Anna Zimmer and René Véron. 2016. "Ponds, Power and Institutions: The Everyday Governance of Accessing Urban Water Bodies in a Small Bengali Town." International Journal of Urban and Regional Research. doi: 10.1111/1468-2427.12377

Demaria, Federico and Seth Schindler. 2016. “Contesting Urban Metabolism: Struggles over Waste-to-Energy in Delhi, India." Antipode 48(2): 293-313.

Denis, Eric, Partha Mukhopadhyay and Marie-Hélene Zérah. 2012. "Subaltern Urbanisation in India." Economic and Political Weekly 47(30): 52-62.

Desai, Renu. 2012. "Entrepreneurial Urbanism in the Time of Hindutava: City Imagineering, Place Marketing, and Citizenship in Ahmedabad." Pp. 31-57 in Urbanizing Citizenship: Contested Spaces in Indian Cities, edited by R. Desai and R. Sanyal. New Delhi: Sage.

Desai, Renu and Romola Sanyal. 2012. "Introduction. Urbanizing Citizenship: Contested Spaces in Indian Cities." Pp. 1-28 in Urbanizing Citizenship: Contested Spaces in Indian Cities. New Delhi: SAGE Publications.

Ernstson, Henrik. 2014. "The Political Nature of Urban Wetlands: Speaking from Princess Vlei Wetland, Cape Town." Urban Wetlands: South Asia May (2): 2-5.

Fernandes, Leela. 2004. "The Politics of Forgetting: Class Politics, State Power and the Restructuring of Urban Space in India." Urban Studies 41(12): 2415-30.

Fischer, Frank. 2000. Citizens, Experts, and the Environment: The Politics of Local Knowledge: Duke University Press. 
Follmann, Alexander. 2015. "Urban Mega-Projects for a 'World-Class' Riverfront: The Interplay of Informality, Flexibility and Exceptionality along the Yamuna in Delhi, India." Habitat International 45(3): 213-22.

Forsyth, Tim. 2003. Critical Political Ecology: The Politics of Environmental Science. London: Routledge.

Forsyth, Tim. 2004. "Industrial Pollution and Social Movements in Thailand." Pp. 422-38 in Liberation Ecologies: Environment, Development, Social Movements, edited by R. Peet and M. Watts. London and New York: Routledge.

Foucault, Michel. [1977] 1991. Discipline and Punish: The Birth of Prison. London: Penguin.

Foucault, Michel. 1997. The Politics of Truth. New York: Semiotext(e).

Ghertner, D. Asher. 2011. “Green Evictions: Environmental Discourses of a ‘Slum-Free’ Delhi.” Pp. 145-65 in Global Political Ecology, edited by R. Peet, M. Watts and P. Robbins. London and New York: Routledge.

Ghertner, D. Asher. 2013. “Nuisance Talk: Middle-Class Discourses of a Slum-Free Delhi.” Pp. 24975 in Ecologies of Urbanism in India: Metropolitan Civility and Sustainability, edited by K. Sivaramakrishnan and A. Rademacher. Hong Kong: Hong Kong University Press.

Gidwani, Vinay and Bharati Chaturvedi. 2011. "Poverty as Geography: Motility, Stoppage and Circuits of Waste in Delhi." Pp. 50-78 in Urban Navigations: Politics, Space and the City in South Asia, edited by J. S. Anjaria and C. McFarlane. London, New York and New Delhi: Taylor and Francis.

Gidwani, Vinay and Rajyashree N. Reddy. 2011. “The Afterlives of 'Waste': Notes from India for a Minor History of Capitalist Surplus." Antipode 43(5): 1625-58.

Grove, Kevin. 2009. "Rethinking the Nature of Urban Environmental Politics: Security, Subjectivity, and the Non-human." Geoforum 40(2): 207-16.

Harriss, John. 2007. “Antinomies of Empowerment: Observations of Civil Society, Politics and Urban Governance in India." Economic and Political Weekly 42(26): 2716-24.

Harvey, David. 1993. "The Nature of Environment: Dialectics of Social and Environmental Change." Pp. 1-51 in: Real Problems, False Solutions: The Socialist Register 1993, edited by R. Miliband and L. Panitch. London: Merlin Press.

Hazra, Tumpa and Sudha Goel. 2009. "Solid Waste Management in Kolkata, India: Practices and Challenges." Waste Management 29(1): 470-78.

Heynen, Nik. 2014. “Urban Political Ecology I: The Urban Century.” Progress in Human Geography 38(4): 598-604.

Holston, James. 2009. "Insurgent Citizenship in an Era of Global Urban Peripheries." City and Society 21(2): 245-67.

Holston, James. 2012. “Foreword.” Pp. ix-xii in Urbanizing Citizenship: Contested Spaces in Indian Cities, edited by R. Desai and R. Sanyal. New Delhi: SAGE Publications.

Holston, James and Arjun Appadurai. 1999. “Introduction: Cities and Citizenship.” Pp. 1-20 in Cities and Citizenship, edited by J. Holston. Durham and London: Duke University Press.

Idris, A., B. Inanc, and M. N. Hassan. 2004. "Overview of Waste Disposal and Landfills and Dumps in Asian Countries." Material Cycles and Waste Management 16: 104-10.

Kalpagam, Umamaheswaran. 2014. Rule by Numbers: Governmentality in Colonial India (e-book version). Lanham, Boulder, New York, London: Lexington Books. 
Karpouzoglou, Timothy and Anna Zimmer. 2016. "Ways of Knowing the Wastewaterscape: Urban Political Ecology and the Politics of Wastewater in Delhi, India." Habitat International 54(2): 15060 .

Kim, Soyeun, Godwin Uyi Ojo, Rukhe Zehra Zaidi and Raymond L. Bryant. 2012. "Bringing the Other into Political Ecology: Reflecting on Preoccupations in a Research Field." Singapore Journal of Tropical Geography 33(1): 34-48.

Kumar, S. 2012. "Clean Air, Dirty Logic? Environmental Activism, Citizenship and the Public Sphere in Delhi." Pp. 135-60 in Urbanizing Citizenship: Contested Spaces in Indian cities, edited by R. Desai and R. Sanyal. New Delhi: SAGE.

Lahiri-Dutt, Kuntala. 2014. "Beyond the Water-Land Binary in Geography: Water/Lands of Bengal Re-Visioning Hybridity." ACME: An International E-Journal for Critical Geographies 13(3): 505-29.

Lahiri-Dutt, Kuntala and Gopa Samanta. 2013. Dancing with the River: People and Life on the Chars of South Asia. New Haven, London: Yale University Press.

Lawhon, Mary. 2013. "Situated, Networked Environmentalisms: A Case for Environmental Theory from the South." Geography Compass 7(2): 128-38.

Lawhon, Mary, Henrik Ernstson and Jonathan Silver. 2014. "Provincializing Urban Political Ecology: Towards a Situated UPE through African Urbanism.” Antipode 46(2): 497-516.

Lawhon, Mary, Jonathan Silver, Henrik Ernstson and Joseph Pierce. 2016. "Unlearning (Un)Located Ideas in the Provincialization of Urban Theory.” Regional Studies 50(9): 1611-22.

Loftus, Alex. 2012. Everyday Environmentalism: Creating an Urban Political Ecology. Minneapolis and London: University of Minnesota Press.

Mawdsley, Emma. 2003. “India's Middle Classes and the Environment.” Development and Change 35 (1): 79-103.

Mbembé, Achille and Sarah Nuttall. 2004. "Writing the World from an African Metropolis." Public Culture 16(3): 347-72.

Pucher, John, Nisha Korattyswaropam, Neha Mittal and Neenu Ittyerah. 2005. "Urban Transport Crisis in India." Transport Policy 12:185-98.

Rabinow, Paul and Nikolas S. Rose. 2003. "Introduction." Pp. 1-5 in The Essential Foucault, edited by P. Rabinow and N. S. Rose. New York: The New Press.

Rademacher, Anne. 2011. Reigning the River: Urban Ecologies and Political Transformation in Kathmandu. Durham: Duke University Press.

Rademacher, Anne and K. Sivaramakrishnan. 2013. "Introduction: Ecologies of Urbanism in India." Pp. 1-42 in Ecologies of Urbanism in India: Metropolitan Civility and Sustainability, edited by K. Sivaramakrishnan and A. Rademacher. Hong Kong: Hong Kong University Press.

Ranganathan, Malini. 2011. "The Embeddedness of Cost Recovery: Water Reforms and Associationism at Bangalore's Fringes." Pp. 165-90 in Urban Navigations: Politics, Space, and the City in South Asia, edited by J. S. Anjaria and C. McFarlane. New Delhi: Routledge.

Ranganathan, Malini and Carolina Balazs. 2015. "Water Marginalization at the Urban Fringe: Environmental Justice and Urban Political Ecology across the North-South Divide." Urban Geography 36(3): 403-23.

Robbins, Paul. 2000. "The Practical Politics of Knowing: State Environmental Knowledge and Local Political Economy.” Economic Geography 76(2): 126-44. 
Roy, Ananya. 2014. "Slum-free Cities of the Asian Century: Postcolonial Government and the Project of Inclusive Growth.” Singapore Journal of Tropical Geography 35(1): 136-50.

Roy, Shouraseni and R. B. Singh. 2015. "Role of Local Level Relative Humidity on the Development of Urban Heat Island across the Delhi Metropolitan Region." Pp. 99-118 in Urban Development Challenges, Risks, and Resilience in Asian Mega Cities, edited by R. B. Singh. Tokyo: Springer.

Sharan, Awadhendra. 2013. "One Air, Two Interventions: Delhi in the Age of Environment." Pp. 71-92 in Ecologies of Urbanism in India: Metropolitan Civility and Sustainability, edited by K. Sivaramakrishnan and A. Rademacher. Hong Kong: Hong Kong University Press.

Sharan, Awadhendra. 2014. In the City, out of Place: Nuisance, Pollution, and Dwelling in Delhi. New Delhi: Oxford University Press.

Sharma, Richa and P. K. Joshi. 2015. "The Changing Urban Landscape and its Impact on Local Environment in an Indian Megacity: The Case of Delhi." Pp. 61-81 in Urban Development Challenges, Risks, and Resilience in Asian Mega Cities, edited by R. B. Singh. Tokyo: Springer.

Shatkin, Gavin. 2014. "Contesting the Indian City: Global Visions and the Politics of the Local." International Journal of Urban and Regional Research 38(1): 1-13.

Shaw, Annapurna. 2007. “Introduction.” Pp. xxiii in India Cities in Transition, edited by A. Shaw. Hyderabad: Orient Blackswan.

Shillington, Laura. 2012. "Urban Political Ecology in the Global South: Everyday Environmental Struggles of Home in Managua, Nicaragua." Pp. 295-310 in Urban Theory beyond the West: A World of Cities, edited by T. Edensor and M. Jayne. London and New York: Routledge.

Silver, Jonathan. 2015. "Disrupted Infrastructures: An Urban Political Ecology of Interrupted Electricity in Accra." International Journal of Urban and Regional Research 39(5): 984-1003.

Smith, Neil. 1990. Uneven Development: Nature, Capital, and the Production of Space. Oxford: Blackwell Publishers.

Swyngedouw, Erik. 1997. "Power, Nature, and the City: The Conquest of Water and the Political Ecology of Urbanization in Guayaquil Ecuador.” Environment and Planning A 29(2): 311-32.

Swyngedouw, Erik and Nik Heynen. 2003. "Urban Political Ecology, Justice and the Politics of Scale." Antipode 35(5): 898-918.

Tawa Lama-Rewal, Stéphanie and Marie-Hélène Zérah. 2011. "Urban Democracy: A South Asian Perspective.” South Asia Multidisciplinary Journal 5. Retrieved July 25, 2016 (http:// samaj.revues.org/3188).

The World Bank. 2001. "Making Sustainable Commitments: An Environment Strategy for the World Bank." Washington, DC: The World Bank.

Truelove, Yaffa. 2011. “(Re-)Conceptualizing Water Inequality in Delhi, India through a Feminist Political Ecology Framework.” Geoforum 42(2): 143-52.

Truelove, Yaffa and Emma Mawdsley. 2011. "Discourses of Citizenship and Criminality in Clean, Green Delhi." Pp. 407-25 in A Companion to the Anthropology of India, edited by I. Clark-Deces. Malden: Wiley-Blackwell.

UN-Habitat. 2010. “The State of Asian Cities 2010/11.” Fukuoka: UN-Habitat.

Upadhyaya, Anjoo Sharan. 2014. "Challenges of Urbanization and Environmental Protection in India.” Pp. 151-67 in India's Human Security: Lost Debates, Forgotten People, Intractable Challenges, edited by J. Miklian and A. Kolas. Oxon and New York: Routledge. 
Véron, René. 2006. "Remaking Urban Environments: The Political Ecology of Air Pollution in Delhi." Environment and Planning A 38: 2093-109.

Véron, René. 2010. "Small Cities, Neoliberal Governance and Sustainable Development in the Global South: A Conceptual Framework and Research Agenda." Sustainability 2: 2833-48.

Watts, Michael and Richard Peet. 2004. "Liberating Political Ecology." Pp. 3-47 in Liberation Ecologies: Environment, Development, Social Movements. London: Routledge.

Zimmer, Anna. 2015. “Urban Political Ecology 'Beyond the West': Engaging with South Asian Urban Studies.” Pp. 591-603 in International Handbook of Political Ecology, edited by R. L. Bryant. Cheltenham, U.K. and Northampton, USA: Edward Elgar.

Zimmer, Anna, Natasha Cornea and René Véron. 2016. "Of Parks and Politics: The Production of Socio-Nature in a Gujarati Town.” Local Environment. doi: 10.1080/13549839.2016.1157157.

Zimmer, Anna, Natasha Cornea and René Véron. Forthcoming. "Landscapes of Power: The Urban in Urban Political Ecology." In Defining the Urban: Perspectives across the Academic Disciplines and Professional Fields, edited by D. Iossifova, C. Doll and A. Gasparatos. Farnham: Ashgate.

\section{NOTES}

1. A rich body of theoretical literature challenges a dichotomy between "nature" and "society," and this complicates the rendering of any simple definition of the environment. See: Smith 1990, Harvey 1993, and Swyngedouw 1997.

2. The contributions in this issue deal with cities in the administrative sense: areas that are governed by urban local bodies (ULBs). This is not to indicate that urban environmental politics are not to be found in India's numerous settlement agglomerations that can be understood as urban while being governed through rural bodies (gram panchayats) (Denis, Mukhopadhyay and Zérah 2012).

3. Indeed the Governments of Rajasthan and Haryana have recently (2016) imposed minimum education requirements on those who wish to contest panchayat elections. As such a particular type of knowledge, gained via formal education, has become intimately tied up with a citizen's right to fully participate in the democratic process. See: http://indianexpress.com/article/india/ india-news-india/rajasthan-haryana-panchayat-polls-school-education-prerequisite-womendalits-adivasis-minorities-politics-2861571/. We thank one of the anonymous reviewers for bringing this issue to light.

4. For a discussion of the evolution of UPE see Zimmer (2010) and Heynen (2014).

5. Ghertner does not inscribe his work in the body of UPE literature, and rather draws on Political Ecology (PE) to create a PE in the city. See Angelo and Wachsmuth (2014) and Zimmer, Cornea and Véron (forthcoming) for a discussion of the relationship between UPE and PE.

\section{ABSTRACTS}

This special issue of SAMAJ, composed of six empirical papers and this introduction seeks to throw light on environmental politics in contemporary urban India. Adopting a deliberately 
broad understanding of the environment, to include environmental amenities, urban natural resources and the built environment, the diverse case studies within this issue contribute to an interlinked set of discussions on the politicization of India's urban environment. In doing so they engage with the ways that the environment is entwined with questions of urban citizenship; the role environmental knowledge(s) play(s) in urban environmental politics; and the situated character of urban political ecologies. While these papers employ diverse entry points into the environmental politics of Leh, Puri, Chennai, Bangalore and Delhi they all pay close attention to everyday practices and situated dynamics. As this perspective is applied across various city sizes the results demonstrate on the one hand the heterogeneity of India's urban environments and on the other the pervasiveness of similar environmental politics across diverse sites. The insights from these papers aptly highlight the analytical challenge of considering issues of temporality and intersectionality whilst also recognizing the multi-scalar political-economic and social factors that shape contemporary urban power dynamics and the reproduction of particular urban environments.

\section{INDEX}

Keywords: environmental politics, urban political ecology, India, knowledge, citizenship

\section{AUTHORS}

\section{ANNA ZIMMER}

University of Lausanne, Institute of Geography and Sustainability, Geopolis, Lausanne

\section{NATASHA CORNEA}

University of Lausanne, Institute of Geography and Sustainability, Geopolis, Lausanne University College London, Dept. of Geography 